\title{
THE REVOCABILITY OF MUTUAL OR RECIPROCAL WILLS
}

\author{
Richard J. Partridge \\ I. Impracticability and Possible Injustice of Mutual \\ WILLS
}

The legal complications that impend where a husband and wife, or any two persons, joined by the bonds of love, affection, relationship or any form of common interest, execute joint wills, or wills joint and mutual, are of such an awkward nature as to discourage those forms of testamentary disposition. The simplest type of single or individual testament is susceptible of too many miscarriages of purpose; joint wills and wills joint and mutual or reciprocal multiply the uncertainties of single wills geometrically. Courts of probate, while protesting in a mild and kindly fashion against joint and mutual wills, and reviewing the earlier ban on joint wills, recognize no modern legal objection to properly executed joint and mutual or "double" wills, but the practical objections to them are legion, and the most serious is the plastic state of the law on the question of revocability by the survivor. Let the man who contemplates joining with his wife in a joint will reciprocal in provisions consider the possibility that he will survive his wife by many years, perhaps, and remarry, and desire to provide for his second wife, but be bound by his joint will to devise and bequeath the joint estates of his first wife and himself to an agreed scheme of remaindermen that may include remote cousins or even persons to whom it would be intolerable for him to leave his estate, to the exclusion of his second wife from all participation in his estate, and even to the defeat of her dower interest therein. ${ }^{1}$

${ }^{1}$ Baker v. Syfritt, I47 Iowa 49, I25 N. W. 998 (1910); Lewis v. Lewis, I04 Kan. 269, 178 Pac. 42I (1919). Contra: In re Arland's Estate, I3I Wash. 297, 230 Pac. 157 (1924) (holding that a wife's dower interest in her husband's estate is a superior equity to the interests of a third party remainderman under the mutual will of the husband and a prior wife). 


\section{Mutual and Joint Wills Defined and Distinguished}

A more satisfactory review of the law on the subject of the revocability of joint and mutual wills by the survivor of co-testators might be achieved if the definitions of these types of testaments were more uniform. A leading case ${ }^{2}$ sets forth the generally accepted definition of a joint will as "one where the same instrument is made the will of two or more persons and is jointly signed by them;" and of mutual wills as "the separate wills of two persons which are reciprocal in their provisions." Garrison, V. C., in New Jersey Equity ${ }^{3}$ defines and distinguishes the two as follows: "A testamentary disposition contained in one writing and disposing of property held jointly is, I presume, precisely referred to as a 'joint will;' whereas, the same document, if it refers to and deals with property held separately, would probably be more precisely termed a 'mutual will." "While the latter are not the generally accepted definitions, they at least take cognizance of the ownership of the property involved, which certainly is of some importance in the resolution of the question of the right of the survivor to revoke. Mr. Costigan ${ }^{4}$ recites the most accurate definition of a joint will: "A joint or conjoint will may be defined to be one executed by joint owners of property, or one executed jointly by the owners of separate property who treat the property bequeathed or devised or both, as joint for will purposes and accordingly leave it to the same beneficiary or beneficiaries." This incorporates the definition usually accepted and the definition of Garrison, V. C.5 A joint will which is not mutual or reciprocal is simply the individual will of each of the persons signing it, and is subject to the same rules that would apply if the will were several. ${ }^{6}$ Where joint wills are reciprocal in their terms they are controlled by the same rules of law as to revocation as apply to "double" or mutual wills. In discussing

${ }^{2}$ Frazier v. Patterson, 243 I11. 80, 84, 90 N. E. 216, 217 (1909); see Campbell v. Dunkelberger, 172 Iowa $385,389,153$ N. W. 56,58 (1915).

${ }^{3}$ Deseumeur v. Rondel, 76 N. J. Eq. 394, 399, 74 Atl. 703, 705 (1909).

- Constructive Trusts Based on Promises Made to Secure Bequests, Devises, or Intestate Succession (1915) 28 HARv. L. REv. 237, 247, n. 19.

- Supra note 3. A note in (I907) 20 HARv. L. REv. 3I5 very accurately and briefly classifies the different types of joint and joint and mutual wills.

- Frazier v. Patterson, sispra note 2. 
the question of the revocability of mutual wills, then, the same rules, rhymes and reasons may be assumed to apply with equal force to joint wills reciprocal in their provisions.

\section{Revocabilitẙ of Mutual WiLls}

\section{A. Before Death of Either of Co-testators}

The law appears to be well settled that during the lifetime of both parties to a mutual will, whether or not executed in pursuance of a contract, either party may revoke said will insofar as it purports to dispose of his property, if the other party is given notice of the intention to revolke. ${ }^{7}$

\section{B. After Death of One of Co-testators}

\section{a. Not based on contract}

After one of the parties to mutual wills has died and the survivor has accepted the benefits from the will of the other, it is generally held that the survivor may still withdraw and execute a separate, individual will different in provisions from the mutual or reciprocal wills, provided said mutual wills were made out of the affection of one testator for the other simply, "the result of the union of life and purpose, and not of a negotiation." s

\section{b. Based on Prior Contract}

Where, however, there has been a prior agreement between the parties to make a mutual or reciprocal will, each in consideration of the other, or upon other valuable consideration, the question of revocation by the survivor becomes entangled with the rules of equity governing specific performance and constructive and resulting trusts, and the rules of law defining the rights of third party beneficiaries to set up the original agreement between the co-testators in an action against the estate of the sur-

${ }^{7}$ Frazier v. Patterson, Campbell v. Dunkelberger, both supra note 2.

"Wilson v. Gordon, 73 S. C. 155, 163, 53 S. E. 79, 82 (1905); Cawley's Estate, 136 Pa. 628, 20 Atl. 567 (I890); Edson v. Parsons, I55 N. Y. 555, 50 N. E. 265 (1898). Conira: Frazier v. Patterson, Campbell v. Dunkelberger, both supra note 2 (decided on the ground, which will be considered later, that joint mutual wills need no proof of contract but contain their own evidence thereof). 
vivor thereof for damages for breach of contract. Wills are described as ambulatory instruments, which do not become effective until the death of their authors. By their very nature, therefore, they contain the element of revocability. If a will does not speak until the decease of the testator, and he destroys it before he dies, it may well be said never to have spoken. And this is no less true of double or joint wills than of single wills, because the only condition upon which the law will recognize such wills as valid is that they can be probated and regarded for all purposes testamentary as the separate or single wills of each of the parties thereto. The law of wills would therefore seem to be well settled that all wills are revocable at all times by their authors, ${ }^{9}$ and the only instrument which the surrogate or register of wills is justified in admitting to probate is that which is, in point of time and fact, the last will and testament of the decedent. ${ }^{10}$ Where there exists a prior contract to devise property according to an agreed scheme of distribution, therefore, the question of the liability of the decedent's estate to answer for the decedent's failure to devise, must be resolved under the rules of equity or the law of contracts or both, and not under the law of wills.

Where a remedy is sought against a decedent's estate for breach of his contract to devise his estate according to a scheme of distribution set forth in a mutual or reciprocal will, the first divergence of authorities is encountered on the question of the proof of the contract. (I) Joint and mutual wills are generally held to contain within themselves sufficient evidence of the contract, without definite evidence to the contrary. ${ }^{11}$ It is argued in support of this rule that where two parties execute their wills by the same instrument and in reciprocal terms, it is not possible

' I Williams, Executors (IIth ed. 192I) 9I; I PAge, Wills (2d ed. I926) $\$ 88$; THEOBALD, Wills (8th ed. I927) I7.

${ }^{10}$ Costigan, supra note 4 , at $248,249, \mathrm{n} .24$.

${ }^{11}$ Dufour v. Pereira, I Dick. 419 (1769); Frazier v. Patterson, supra note 2; Rastetter v. Hoenninger, 214 N. Y. 66, 108 N. E. 210 (1915); Campbell v. Dunkelberger, supra note 2 ; Bower v. Daniel, 198 Mo. 289, 95 S. W. 347 (I906). Contra: Cawley's Estate, supra note 8; see Ginn v. Edmundson, 173 N. C. 85,87 , 91 S. E. 696,697 (I9I7) (to the effect that a joint will devising an estate held by co-testators, as tenants by the entireties, contains no evidence of a prior contract between the parties); Hoffert's Estate, $65 \mathrm{~Pa}$. Super. 515 (I9I7). 
that such course could be adopted without some previous understanding or agreement between them. (2) Wills mutual or reciprocal, but not joint, however, are held to require additional evidence of the contract. ${ }^{12}$ In such cases the mere coincidence of mutuality is not regarded as conclusive evidence of the contract. In this respect, at least, the law as to the revocability of mutual wills diverges from the law as to the revocability of joint and mutual wills.

Assuming the contract proved and its terms established, there is still an absence of unanimity as to the method of enforcement. The futility of contesting the probate of the revoking will and attempting to secure the probate of the revoked mutual will in the light of the rule that all wills, as such, are revocable, whether or not made in pursuance of a contract, has already been shown. ${ }^{13}$

However, as will be shown later, many courts speak inaccurately of specific performance in the enforcement of such contracts in equity, and in this connection it would seem that the nearest approach to specific performance that could be achieved, after the death of the party upon whom the obligation to perform specifically is sought to be impressed, would be to admit to probate the mutual will in disregard of all later wills in revocation thereof. Here, of course, would arise the question of the jurisdiction of the register of wills or surrogate to give effect to a contract to make a will in disregard of what the testator intended to be his last will and testament. Interested parties under the contract, however, might file their bill in equity prior

${ }^{10}$ Edson v. Parsons, Wilson v. Gordon, both supra note 8.

In Gray v. Trustee Co., [1928] A. C. 39I, and In re Oldham, [I925] Ch. 75, it was held that in order to raise a trust for the disappointed legatees under the mutual wills, in disregard of the revoking will of the survivor, on the grounds that there was an agreement between the parties not to revoke said mutual wills, there must be more particular evidence of the contract not to revoke than the mere mutuality and simultaneity of the mutual wills, which, as evidence, do not go nearly far enough to raise an enforceable trust. In each of these cases the court was at great pains to reconcile its decision with Dufour v. Pereira, supra note 11 , pretending to see in the latter case evidence in addition to the mere mutuality of the will. However, it is difficult to see what additional evidence can be discovered in the very brief report of Dufour v. Pereira, except that the will was both joint and mutual, whereas in the two instant cases the wills were mutual but not jointly executed.

13 See Williams v. Williams, 123 Va. $643,647,96$ S. E. 749,750 (19r8); Costigan, supra note 4 , at 248,249, n. 24 . 
to the probate of the will praying an order upon the register or surrogate to admit to probate as the last will of the decedent the mutual will made in pursuance of the contract under which they claim, whether or not said mutual will is, in fact, the last will and testament of the decedent. Or, after the revoking will has been probated, parties interested under the mutual will might appeal to the equity jurisdiction of the probate or orphans' court to set aside probate of the later will and decree distribution according to the tenor of the mutual will. ${ }^{14}$ Except as the procedure just set forth might prove available, specific performance as a means of enforcing the obligation of the survivor of co-testators to abide by the terms of a mutual or reciprocal will is a misnomer. It has been seen that, under the law of wills, it is pretty definitely settled that all wills, single, joint, joint and mutual, and mutual, are ambulatory and revocable by the survivor. Where, then, the survivor of co-testators revokes the mutual will, and dies, leaving a subsequent will, the parties injured thereby cannot have him specifically compelled to devise as he agreed. ${ }^{15}$ No order of court can require the deceased to emerge from his tomb and execute the will he contracted to publish and declare as his last will and testament. That instrument which is, in point of time, the last will of the decedent, becomes, at least for all purposes testamentary, the last will of the testator, to the exclusion of the mutual will.

Many cases speak inaccurately of specific performance of the contract to make mutual wills. Analyzed, the remedies they afford are revealed as constructive or resulting trusts impressed upon the property which was the subject of the contract. ${ }^{16} \mathrm{~A}$

14 In Frazier v. Patterson, supra note 2, the court, in the exercise of its equity jurisdiction, set aside the probate of the revoking will and decreed partition of the decedent's estate in accordance with the terms of the mutual will.

${ }^{15}$ Pomeroy, Specific Performance, 36 Cyc. 735.

${ }^{16}$ Williams v. Williams, supra note I3; see Kine v. Farrell, 7 I App. Div. $219,220,75 \mathrm{~N}$. Y. Supp. 542, 543 (I902). In White v. Winchester, I24 Md. 518 , 92 Atl. I057 (1915), contracts to make or not to alter a will were enforced by fastening a trust on the property, which was the subject of the contract to devise, and requiring the devisee, or a trustee appointed for the purpose, to make a conveyance in accordance with the terms of the contract. But in these cases the enforcement of the contracts was in favor of original parties to the contract. 
trustee is appointed by the court to receive the property and to execute a deed of conveyance thereof to the parties entitled under the terms of the contract or the mutual will itself, if it alone evidences the contract. Or the legal title of the persons who take the property under the revoking will is charged with a trust for the performance of the testator's agreement in favor of the parties claiming under the mutual will. Mr. Costigan calls this remedy "quasi-specific performance," 17 i. e., the testator is not compelled to execute the will he agreed to execute, nor is probate of the mutual will ordered, but equity directs the distribution of the decedent's estate according to such will as he contracted to make and in disregard of the will he actually executed and allowed to remain as his last will. The property is ordered partitioned as though the testator had been specifically compelled to execute the mutual will, although he manifestly cannot be compelled so to do. In several very interesting cases, ${ }^{18}$ however, the doctrine of specific performance was literally applied against the survivor of co-testators in his life-time. In each case the parties interested under the mutual will successfully enjoined the survivor from disposing of his estate by will otherwise than as agreed in the mutual will under which their rights arose.

Breach of a contract to abide by the terms of a joint mutual will or separate mutual wills, where the contract satisfies the requirements of the Statute of Frauds, may also be rectified in an action at law for damages against the estate of the survivor of the co-testators, ${ }^{19}$ just as breaches of contracts to devise can be indemnified. ${ }^{20}$

But the limitations of "third party beneficiaries" and the unwillingness of the courts to extend the doctrine of Larerence v. Fox, ${ }^{21}$ arise as the obstacles to recovery at law by strangers to the contract who seek to claim against the estate under the mu-

\footnotetext{
${ }^{27}$ Supra note 4, at $25 \mathrm{r}$.

${ }^{28}$ Campbell v. Dunkelberger, supra note 2; Carmichael v. Carmichael, 72 Mich. 76,40 N. W. 173 (1888).

${ }^{10}$ PAGE, loc. cit. sispra nate 9.

${ }^{20}$ Jenkins v. Stetson, 9 Allen I28 (Mass. 1864).

20 N. Y. 268 (1859). For a discussion of the present status of this doctrine in Pennsylvania see Corbin, The Law of Third Parly Beneficiaries in Pennsylvania (I928) 77 U. OF PA. L. REV. I.
} 
tual will. In the usual cases of mutual wills the co-testators agree to devise their separate estates to the survivor for life (usually with power to consume), and at his or her death, to an agreed scheme of remaindermen, none of whom furnished any consideration for the contract, and who, in the contemplation of the law, are strangers thereto and quite without the protection of the doctrine of Lawrence $v$. Fox. Third party beneficiaries are even less fortunate where they attempt to exact specific performance of such a contract, for equity recognizes almost any substantial circumstance in defeat of the aforementioned doctrine of Lazerence v. Fox. ${ }^{22}$ And the courts of probate tend to invoke every available pretext to protect the individual in his right to devise his estate voluntarily and according to the dictates of his natural will, especially against the claims of mere volunteers. ${ }^{23}$ For instance, the survivor might live twenty or thirty years after the death of his co-testator, or circumstances might arise which would make it intolerable for the survivor to be compelled to devise a share in his estate to one or more of the agreed legatees in remainder, or his property might accumulate to an extent unforeseen at the time the mutual will was executed. Equity would certainly hold mutual wills revocable under such circumstances, in the first two cases because of the injustice of enforcing the suspension of a man's right to bequeath his property according to his natural will throughout the changes of mind and circumstance of twenty or thirty years, and in the third case because of the inadequacy of the original consideration to control the devise of the unexpected accumulation of property. These considerations acquire additional strength where the contract appears

${ }^{2}$ Wait v. Wilson, 86 App. Div. 485,83 N. Y. Supp. 834 (1903). An agreement between husband and wife that the latter should devise to the former's son by a prior wife so much of the property willed to her by her husband as should remain unconsumed at her death was held not to entitle the son, in the event of the step-mother's dying without performing the contract, to maintain an action for specific performance, where he was not a party to the contract and no consideration moved from him to either of the parties, it not appearing that he was an infant at the time the contract was made or that either of the parties thereto was under any legal or equitable obligation to him. And the court so held even though the widow had enjoyed the benefits of the husband's will as a result of her contract to devise to his son at her death.

${ }^{2}$ Mehl's Estate, 9 Pa. D. \& C. 732 (I926). 
to be primarily for the benefit of the contracting parties themselves (as where the power to consume is given), and for the benefit of third parties in remainder only, and where the property, which is the subject of the agreement, did not in any sense belong to such third parties, was not transferred to the use of such third parties, and where no privity existed between either of the contracting parties and the third parties claiming in remainder, and no obligation, legal or equitable, was owing to said third parties by either of the co-testators. ${ }^{24}$ The rules as to proof of the contract, already considered, likewise appear to be construed less liberally in favor of pure volunteers. ${ }^{25}$ Where, however, the remaindermen under the double will are. the heirs and next of kin of the first decedent, the objection that they are third party beneficiaries, who furnished no consideration for the contract, would seem to be dissipated. Their right to share in the distribution of the decedent's estate, had he died intestate, would seem to entitle them to be subrogated to the rights of the decedent himself, and remove them from the prohibitive classification, "third party beneficiaries." Certainly in such a case the chief objection to third party claims-that the promisor might be liable to two actions on the same contract, one brought by the promisee and one by the third party beneficiary-is obviated by the merger of the two interests in the latter, by succession to all the right, title and interest in the estate of the former.

"In McGinley's Estate, 257 Pa. 478, Ior Atl. 807 (1917), a mutual will was enforced against the estate of the survivor of co-testators in favor of third parties who had furnished consideration therefor in the form of services rendered to the co-testators.

$\approx$ In Hoffert's Estate, supra note II, the argument was advanced that an instrument jointly executed by a husband and wife, whereby each agreed to devise certain real estate, to which they held title as tenants by the entireties, to a certain party on the death of the survivor, was a contract for the benefit of third parties and enforceable by them against the executor of the survivor, but the court held the instrument to be a double will revocable by the survivor, said instrument in all respects complying with the requirements of a double will and having been designated a will by the parties themselves. The court calls attention to the careful distinction drawn in Cawley's Estate, supra note 8, between a contract and a will, and decides that there was neither any consideration for a contract, nor any intent to create a contract, and recognizes the revocability by the survivor of the double will standing alone. As between the parties themselves, however, it is difficult to see how the court could have avoided the conclusion, from the very language of the will, that it constituted a contract in its own terms. 
Where the right of the survivor to revoke the mutual will, after accepting the benefits thereunder, is recognized, such revocation must be understood to affect only the separate property of the survivor, and the remainder of the property of his cotestator, at the death of said survivor and the termination of his life estate, is distributable according to the terms of the double will, which, despite revocation by the survivor as to his own property, continues the last will and testament of his co-testator. ${ }^{26}$ There is, of course, no originality in this rule; it is but the well-established rule that a life tenant with power to consume, who has not used or consumed the property during life, will not be permitted by will to give it to persons other than those designated by the testator. ${ }^{2 T}$

\section{Transferability of Interest of Beneficiary Under Mutual Will-Interest Vested or Not}

The question whether or not remaindermen under mutual wills take vested remainders in the life-time of the surviving co-testator can only be resolved upon an examination of the special circumstances of each case considered in the light of all that has been said upon the subject of revocability by the survivor. In a jurisdiction that holds such wills revocable by the survivor, the interests of remaindermen in the life-time of the surviving co-testator, during which time the possibility of revocation is ever present, are, at best, vested subject to be divested. In a jurisdiction that holds mutual wills binding upon the survivor and irrevocable by him, the interests of remaindermen thereunder would seem to be vested and capable of assignment or transfer. A recent case, ${ }^{28}$ however, held that such interest was not vested so as to pass to a trustee in bankruptcy, even though the contract not to revoke the mutual will was binding upon the survivor. Certainly the remaindermen would seem to take vested interests in that portion of the estate of the co-testator first deceased which

\footnotetext{
${ }^{23}$ Morgan y. Sanborn, 225 N. Y. 454, 122 N. E. 696 (I919); Mehl's Estate, supra note 23.

27 Tyson's Estate, I9I Pa. 218, 43 Atl. I3I (I899).

${ }^{28}$ In re Lage, I9 F. (2d) I53 (N. D. Iowa I927).
} 
remained unconsumed and capable of identification as part of his estate at the death of the survivor, whether or not mutual wills are held revocable by the survivor. The mutual will, in spite of its revocation by the survivor as to his property, still subsists as the will of his co-testator, and under it the surviving co-testator takes only a life estate, with or without power to consume, and distribution of the unconsumed portion at the termination of the latter's life estate must be made to the remaindermen designated in the mutual will. ${ }^{29}$

\section{Public Policy}

Public policy must be said to look with disfavor upon mutual wills if, as appears above, ${ }^{30}$ they can bar the dower interest of a subsequent wife of a surviving co-testator, to the profit of remaindermen who are pure volunteers, and who, since the mutual will was executed, may have become discredited in the contemplation of the surviving co-testator. And this is said in the face of judicial expression to the contrary. ${ }^{31}$ Courts of probate are inclined to shelter the individual in his right to dispose voluntarily of his property by will, and treat with suspicion any device that threatens to restrict the free exercise of his will in the disposition of his property. ${ }^{32}$ And until third party beneficiaries attain a more cordial recognition than that reluctantly afforded them in Lawrence $v . F_{o x},{ }^{33}$ public policy will continue to weigh heavily against the granting of legal or equitable relief to clainants under mutual wills, whose interests have been prejudiced by revocation. Contracts to devise, it is true, are not generally regarded as objectionable; claimants under such contracts are usually parties thereto who have furnished good and valuable consideration. Justifiable claims will arise, too, of third parties who have furnished valuable consideration for the contracts of co-testators to devise to each other reciprocally and in remainder

\footnotetext{
${ }^{2}$ Morgan v. Sanborn, supra note 26; Mehl's Estate, supra note 23.

${ }^{30}$ Baker v. Syfritt, Lewis v. Lewis, both supra note I.

${ }^{1}$ Lewis v. Lewis, supra note $\mathrm{I}$.

is Mehl's Estate, supra note 23.

${ }^{3}$ Supra note $2 \mathrm{I}$.
} 
to said third parties. ${ }^{34}$ But beyond the point where the claimants in remainder under mutual wills furnished some valuable consideration therefor, or the parties themselves stood in some legal or equitable relation of responsibility or trust to said claimants, public policy threatens to interpose the legal prohibitions of inadequacy of consideration and the third party beneficiary doctrine, and the equitable defense of hardship to frustrate the claims of disappointed remaindermen and reserve to the survivor, undiminished, his right to revoke the mutual will, so far as it purports to dispose of his property, and to dispose thereof by testamentary direction according to the voluntary dictates of his natural individual will.

3s McGinley's Estate, supra note 24. 